\title{
ASSESSING THE WELD QUALITY OF MANGANESE STEEL
}

\author{
Rastislav BERNÁT, Zoltán ZÁLEŽÁK, Norbert KECSKÉS, Peter BLAŠKO \\ Slovak University of Agriculture in Nitra, Slovakia
}

\begin{abstract}
The welding of alloy steels in practice is a difficult process in order to achieve mechanically or chemically resistant high-quality welds. In some cases, the weldability of many materials can be difficult or is not recommended because of poor and unsuitable properties of welded joints. In our research work, we investigate the selection of an appropriate welding method for welding the manganese steel HS 20 used at dynamically strained components in the car industry. The welding methods have been selected from accessible methods of the KARRER, s.r.o. Tovarníky industrial plant. Based on the comparable welding technologies MMA, MIG/ MAG and TIG, we tested and verified the quality of welds by means of selected weld tests. The quality of these welds, obtained by the abovementioned methods, was evaluated by weld tests in laboratory conditions of the Department of Quality and Engineering Technologies (Slovak University of Agriculture in Nitra) in cooperation with NDB, s.r.o. Bratislava and SES TImače, a.s. The aim of the research work is to set the most suitable and effective method of welding for given components from all the technologies available in the mentioned industrial plant. Based on relevant information, we also want to enrich the scope of knowledge about welding of manganese materials in order to make the welding process more effective.
\end{abstract}

Keywords: quality monitoring, weld, MIG/MG, TIG, examination of welds

The principal aim of all welding technologies is to create perfect welded joints the properties of which are similar to those of a homogenous base material (Balla, 2013). Problems with general weldability of materials can be reduced or fixed by proper selection of materials to be welded, by proper technology and by implementation of certain constructional modifications necessary for successful welding (Žernovič et al., 2006). It means that weldability is influenced by three interconnected factors - material, technology and construction. These three factors cannot be considered separately but always in complexity (Hrivňák, 2009).

The valid norm defines the weldability as a complex characteristic of material which determines its technical suitability for joints of demanded quality. Weldability refers to the whole welded joint, not only to basic material (Kaloč and Beneš, 2009).

Nowadays, we know many technological methods of welding as a result of the development of new materials and technologies. Welding should be treated as an inseparable part of industrial production and reparation (Krchnák et al., 2011).

Used high-quality alloy steels contain large amounts of various elements and their presence influences the weldability (Turňa, 1989). In our paper, we deal with the problem of welding the manganese steel HS 20, which represents a high-quality alloy and which requires more attention (Tolnai, 2000).

According to our experiments, we want to propose an appropriate welding technology of manganese steels to be used in the abovementioned industrial plant.

\section{Material and methods}

Obtaining a perfect welded joint the properties of which are similar to that of a homogenous basic material is rather difficult because of the presence of various alloying adulterants. These adulterants significantly change the properties of welded metal (Balla, 2003).

In our research work, we investigate the properties of structural steels alloyed with manganese. Manganese positively influences the mechanical and abrasion-proof properties of such steels. The manganese steel contains minimally $0.9 \%$ of $\mathrm{Mn}$. These steels are very tough and nonmagnetic materials with difficult weldability.

Surfaces of welded joints were formed intol-shaped welds. The basic material was the steel HS 20, defined according to the norm BS 1449-1.1:1991. Its thickness is $3.30 \mathrm{~mm}$. The analysis of the chemical composition of HS 20 was carried out by the CORUS company and is shown in Table 1.

Table 1 Chemical composition of HS 20

\begin{tabular}{|l||c|c|c|c|c|c|}
\hline & C & Si & Mn & P & S & Al \\
\hline \hline Min. in \% & 0.200 & 0.150 & 1.400 & - & - & 0.020 \\
\hline Max. in \% & 0.250 & 0.300 & 1.700 & 0.025 & 0.025 & 0.050 \\
\hline $\begin{array}{l}\text { Analysis of the } \\
\text { material in \% }\end{array}$ & 0.220 & 0.240 & 1.520 & 0.014 & 0.013 & 0.035 \\
\hline
\end{tabular}

Source: Corus, 2008

Mechanical properties of HS 20 according to the norm BS 1449-1.1:1991: limit yield value $R e=\min$. $340 \mathrm{MPa}$, ultimate strength value $R_{m}=\min .460 \mathrm{MPa}$ and ductility $A_{5}=\min$. $18 \%$.

In order to obtain high-quality welds, the selection of appropriate welding technology and equipment is essential (Kováč et al., 2005). We have chosen two economically accessible and comparable technologies. For these technologies, we took proper filler materials and set the corresponding parameters of welding.

For the welding technology MIG/MAG, we used the welding unit STEL HI-MIG 500P with the wire feeder STEL 
Table 2 Parameters of welding with MAG

\begin{tabular}{|c|c|c|c|c|c|c|c|c|c|}
\hline & $\begin{array}{l}\text { Position of } \\
\text { welding }\end{array}$ & $\begin{array}{l}\text { Welding } \\
\text { direction }\end{array}$ & $\begin{array}{c}\text { Root gap } y \\
\text { in } \mathbf{m m}\end{array}$ & $\begin{array}{c}\text { Angle } \\
\text { of tilt } a \text { in }\end{array}$ & $\begin{array}{c}\text { Wire feeder speed } \\
\text { vd in } \mathrm{m} \cdot \mathrm{min}^{-1}\end{array}$ & $\begin{array}{c}\text { Time of } \\
\text { welding } t \text { in } s\end{array}$ & $\begin{array}{c}\text { Voltage U } \\
\text { in V }\end{array}$ & $\begin{array}{c}\text { Current I } \\
\text { in A }\end{array}$ & $\begin{array}{c}\text { Speed of welding } \\
v \text { in } \mathrm{mm}^{-1}\end{array}$ \\
\hline MAG & horizontal & forward & 4 & 45 & 2.8 & 240 & 17.9 & 50 & 0.7 \\
\hline
\end{tabular}

Table 3 Parameters of welding with TIG

\begin{tabular}{|c|c|c|c|c|c|c|c|c|}
\hline & $\begin{array}{l}\text { Position of } \\
\text { welding }\end{array}$ & $\begin{array}{l}\text { Welding } \\
\text { direction }\end{array}$ & $\begin{array}{c}\text { Root gap } y \text { in } \\
\text { mm }\end{array}$ & $\begin{array}{l}\text { Angle of tilt } \\
\quad a \text { in }{ }^{\circ}\end{array}$ & $\begin{array}{c}\text { Time of } \\
\text { welding } t \text { in } s\end{array}$ & $\begin{array}{c}\text { Speed of welding } \\
v \text { in } \mathrm{mm} \cdot \mathrm{s}^{-1}\end{array}$ & $\begin{array}{c}\text { Voltage } \\
U \text { in V }\end{array}$ & $\begin{array}{l}\text { Current I } \\
\text { in } A\end{array}$ \\
\hline TIG & horizontal & forward & 2.5 & 45 & 240 & 0.7 & 28 & 80 \\
\hline
\end{tabular}

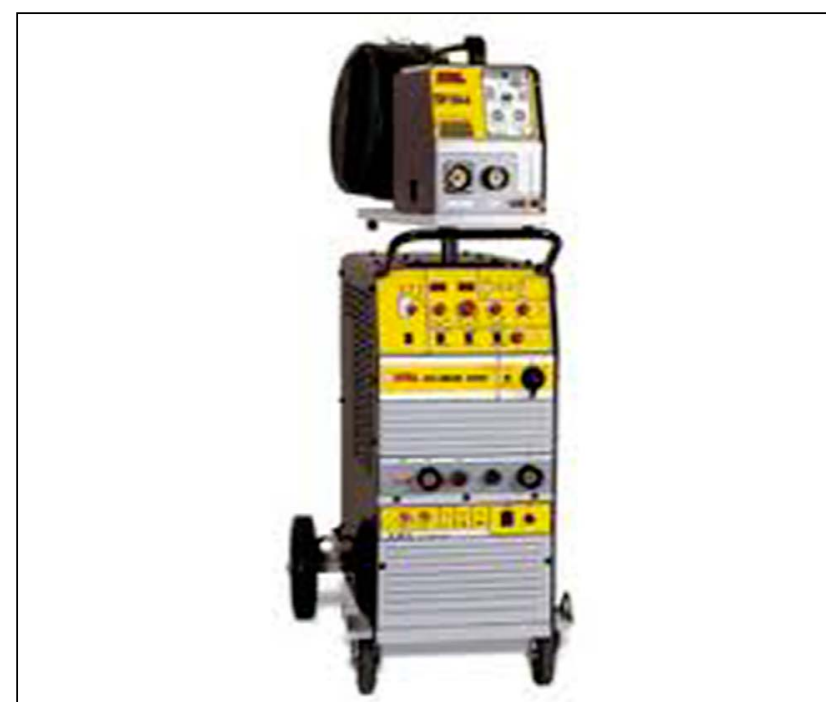

Figure 1 STEL HI-MIG 500P

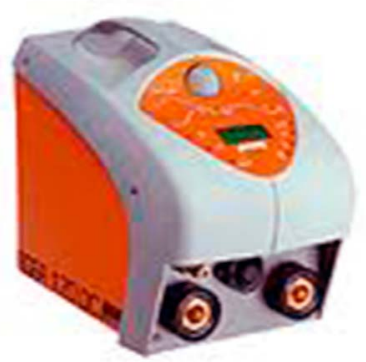

Figure 2 TIGER 210 AC/DC

TOP 504-A (Fig. 1). Here, we worked with a two-component mixture of carbon dioxide and argon in ratio $82 \% \mathrm{Ar}$ and $18 \% \mathrm{CO}_{2}$. The filler material was EN 440: G $464 \mathrm{M} \mathrm{G3Si1}$ (SG 2 for MAG) with diameter $d=0.8 \mathrm{~mm}$.

The welding technology TIG used the universal welding equipment TIGER 210 AC/DC (Fig. 2) in an argon inert atmosphere, and we used EN 1668: W 425 W3Si1 (SG 2 for TIG) with diameter $d=2.4 \mathrm{~mm}$ as a filler material.

All welds welded by the technologies TIG and MAG were subjected to:

- visual test (instantly after welding and cooling), capillary test (after 24 hours after welding), X-ray test, transverse tensile test, fracture test, metallographic test, and stiffness test.

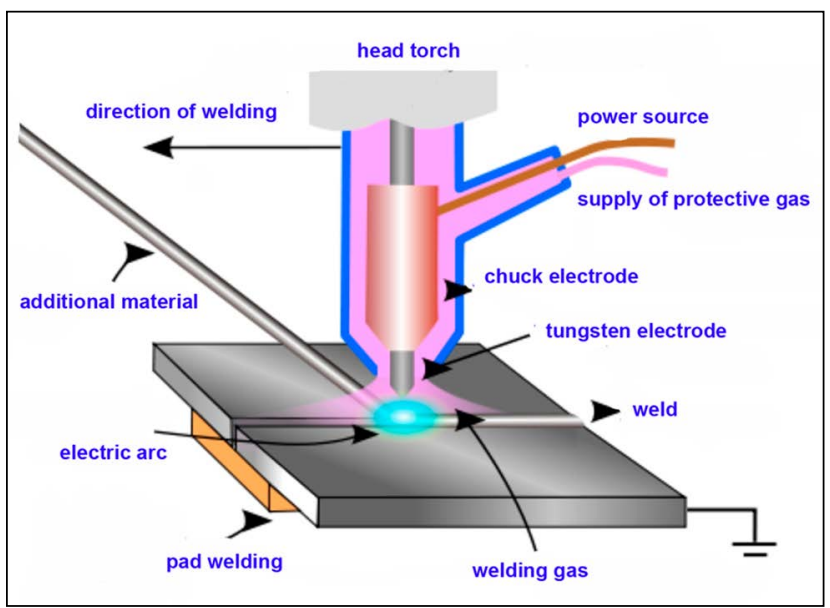

Figure 3 Principle of TIG welding

Source: Tolnai, 2000

\section{Results and discussion}

\section{Visual test of welded joints}

This test was carried out and evaluated in accordance with the norm EN ISO 5817 Class 'B' at all samples of welded joints.

The evaluation of the MAG (Fig. 4) technology showed visible pores, and the whole root was welded thoroughly. This method of welding created visible deformities and unevenness of welds, which require further elaboration.

The TIG technology created welds without crevices and pores (Fig. 5). The root was thoroughly welded, and in this case, deformity was the lowest. The thickness of the material HS 20 (3.3 mm) did not allow us to avoid deformation while fixing the sample.

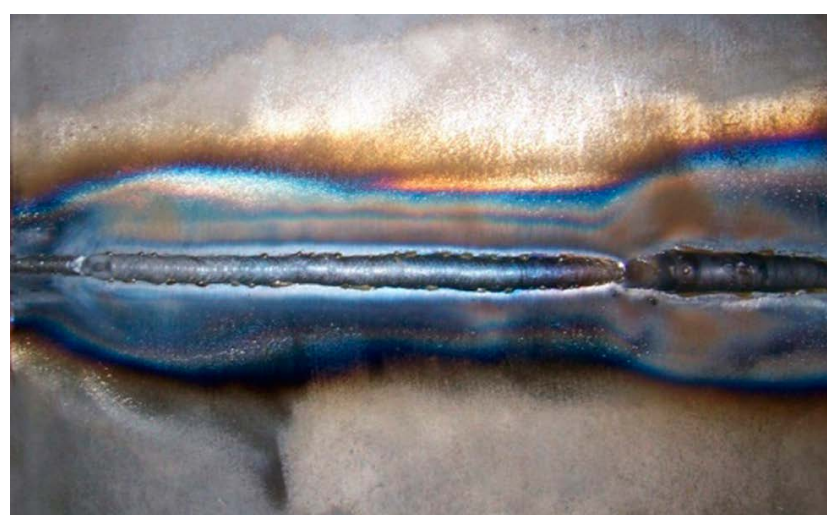

Figure 4 Weld obtained by the MAG technology 


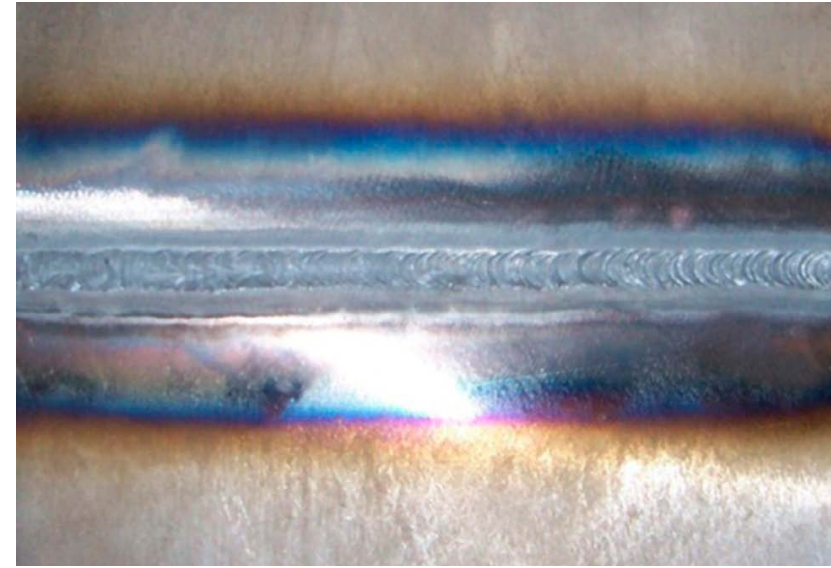

Figure 5 Weld obtained by the TIG technology

\section{Capillary test of welded joints}

The capillary test was carried out in conformity with the EN ISO 3452-2 norm for detection of surface crevices with the aid of penetrant by the method TEST-70-9802 where the temperature of the surface was $18{ }^{\circ} \mathrm{C}$. The penetration time was 15 minutes, and then the detection substance was applied for next 5 minutes to show defects on the surface of the weld.

Both technologies TIG and MAG were subjected to the capillary test. On the surface of the TIG and MAG welds, there were surface crevices detected and hence they were evaluated as unacceptable.

\section{X-ray test of welded joints}

The X-ray test of welded joints was evaluated in accordance with the EN 12517/1 norm and has revealed internal nonhomogeneities of the material. We used an X-ray sensitive film to visualize the defects.

The welded joint obtained by the MAG technology was divided into three areas where weld defects were identified on the X-ray film. In one area, we found pores and cold weld marks in the extent that does not comply with the EN 12517/1 norm. The welded joints obtained by the TIG technology were also divided into areas (Fig. 6). In this case, all areas met the required criteria and proved the suitability of this technology in practice.

Table 4 Results of mechanical pulling test

\begin{tabular}{|l||c|c|c|c|}
\hline $\begin{array}{l}\text { Number of } \\
\text { the sample }\end{array}$ & $\begin{array}{c}\boldsymbol{F}_{\boldsymbol{m}} \\
\text { in } \mathbf{k} \mathbf{N}\end{array}$ & $\begin{array}{c}\boldsymbol{R}_{\boldsymbol{m}} \\
\text { in } \mathbf{M P a}\end{array}$ & $\begin{array}{c}\text { Place of } \\
\text { rupture }\end{array}$ & Evaluation \\
\hline $\begin{array}{l}822-1 \\
\text { E 307-16 }\end{array}$ & 37.25 & 501 & $/ \mathrm{ZV/}$ & passed \\
\hline $\begin{array}{l}822-6 \\
\text { E-R } 117\end{array}$ & 43.51 & 582 & $/ \mathrm{ZM} /$ & passed \\
\hline $\begin{array}{l}822-11 \\
\text { TIG }\end{array}$ & 45.84 & 589 & $/ \mathrm{ZM} /$ & passed \\
\hline $\begin{array}{l}822-12 \\
\text { TIG }\end{array}$ & 45.24 & 567 & /ZM/ & passed \\
\hline $\begin{array}{l}822-14 \\
\text { MAG }\end{array}$ & 44.88 & 575 & /ZM/ & passed \\
\hline $\begin{array}{l}822-15 \\
\text { MAG }\end{array}$ & 44.32 & 583 & /ZM/ & passed \\
\hline
\end{tabular}

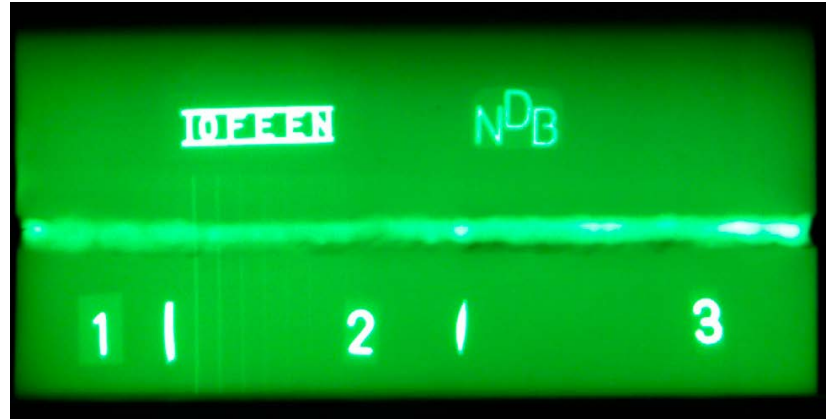

Figure 6 X-ray film technology TIG

\section{Transverse tensile test}

This test serves as a basic test for examination of mechanic and plastic characteristics. By this test we found the tension characteristic - the ultimate strength value $R_{m}$ in MPa. The test was carried out in accordance with the STN EN ISO 4136:2011-09 norm by the machine EU 40. The measured values are listed in Table 4 . The result of the transverse tensile test for the sample 822-12 TIG is shown in Fig. 7.

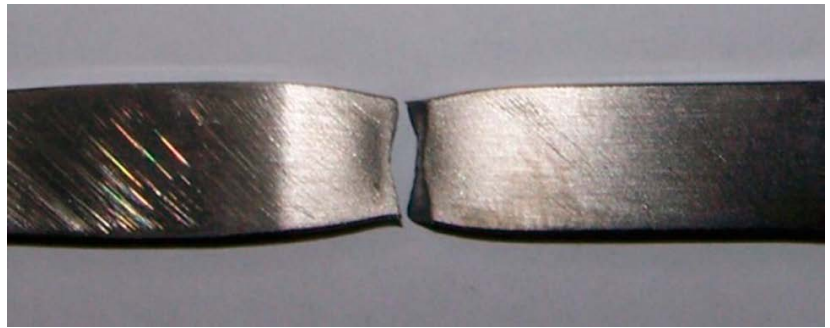

Figure 7 Sample 822-12, TIG method

\section{Fracture test}

The principle of this test is in plastic deformation of the welded joint by a loading wedge up to the prescribed angle of deflection or up to appearing of ruptures visible without magnification (STN EN ISO 7438:2006-01; Brziak et al., 2003).

The fracture test was carried out in accordance with the STN EN ISO 5173:2010-10 norm using the machine EU 100. Welded joints were tested from the root side (RBB). The results are listed in Table 5.

Table 5 Results of mechanical fracture test

\begin{tabular}{|l||c|c|c|c|}
\hline $\begin{array}{l}\text { Number of } \\
\text { the sample }\end{array}$ & $\begin{array}{c}\text { Side of } \\
\text { the weld }\end{array}$ & $\begin{array}{c}\text { Angle of } \\
\text { deflection a }(\mathbf{0})\end{array}$ & $\begin{array}{c}\text { Diameter } \\
\phi \mathbf{~ i n ~} \mathbf{~ m m}\end{array}$ & Evaluation \\
\hline \hline $\begin{array}{l}822-2 \\
\text { E 307-16 }\end{array}$ & RBB & $180^{\circ}$ & 15 & refused \\
\hline $\begin{array}{l}822-5 \\
\text { E-R 117 }\end{array}$ & RBB & $180^{\circ}$ & 15 & refused \\
\hline $\begin{array}{l}822-8 \\
\text { TIG }\end{array}$ & RBB & $180^{\circ}$ & 15 & passed \\
\hline $\begin{array}{l}822-9 \\
\text { TIG }\end{array}$ & RBB & $180^{\circ}$ & 15 & passed \\
\hline $\begin{array}{l}822-17 \\
\text { MAG }\end{array}$ & RBB & $180^{\circ}$ & 15 & passed \\
\hline $\begin{array}{l}822-18 \\
\text { MAG }\end{array}$ & RBB & $180^{\circ}$ & 15 & passed \\
\hline
\end{tabular}




\section{Conclusion}

The welding of manganese steels can be done by different technologies (Tolnai, 2000). In our research, we compared the suitability of the technologies MIG/MAG and TIG for welding the material HS 20 defined by the norm BS 1449-1.1:1991.

The results of the tests expressly confirmed the fact that the proper selection of suitable welding technology and the amount of heat given to the joint significantly influences the quality of welds of manganese steels (Krchnák et al., 2011).

The first presumption that the TIG welding technology is the most suitable for manganese steel welding was the result of the visual test. There were no visible welding pores, the root was perfectly welded and the superelevation was the most adequate. When the MIG/MAG technology was used, pores were visible. Irregularities of superelevation were also found as unacceptable compared to the TIG technology.

The capillary test of the whole comparison confirmed that the technologies TIG and MIG/MAG are not acceptable for welding manganese steels. By means of penetrant, there were crevices found on the surface of joints.

The X-ray test confirmed the results obtained by the capillary test for the MIG/MAG technology. We observed visible pores, partly molten edges and cold weld marks. The TIG method, based on the X-ray film, appears to be the most suitable method for welding the material HS 20; however, it is necessary to define the parameters of welding and improve the skills of welders.

When evaluating the transverse tensile test, after the ultimate strength values obtained had been processed and compared to the defined value in accordance with the BS 1449-1.1:1991 norm, where $\mathrm{Rm}=\min .460 \mathrm{MPa}$, it was found that all obtained measured values were higher than $460 \mathrm{MPa}$. It means that the samples of joints meet the requirements of the given norm.

The material HS 20 is difficult to be welded, and when it was subjected to the fracture test, the TIG and MAG welds were found to be suitable.

Following the exact welding procedures, carrying out the tests in accordance with the given norms and the evaluation of all results led to the conclusion that the most suitable method for welding the material $\mathrm{H} 2 \mathrm{O}$, with the minimum heat influence on the material, with the lowest level of deformation and acceptable mechanical attributes, is the TIG technology.

\section{References}

BALLA, J. 2003. Náuka o materiáloch. Nitra : SPU. 2003. ISBN 80-8069-249-1.

BERNÁT, R. - KROČKO, V. - DRLIČKA, R. 2009. Quality evaluation of milled hardface layers. In TechMat 2009 - Perspektivní technologie a materiály pro technické aplikace. Pardubice: Univerzita Pardubice, 2009. s. 209-214. ISBN 978-80-7395-046-0.

BRZIAK, P. et al. 2003. Materiály a ich správanie sa pri zváraní. Bratislava : VUZ. 2003. ISBN 80-88734-10-X.

BS 1449-1.1:1991. Steel plate, sheet and strip. Carbon and carbonmanganese plate, sheet and strip. General specification.

HRIVŇÁK, I. 2009. Zváranie a zvaritel'nost’ materiálov. Bratislava. 2009. ISBN 9788022731676.

KALOČ, R. - BENEŠ, L. 2009. Analytical prediction of bifurcation process in an adhesive rolling kinematic pair. In Sborník vědeckých prací Univerzity Pardubice (Scientific Papers of the University of Pardubice), Series B. Pardubice : The Jan Perner Transport Faculty, 2009. pp. 75-80. ISBN 978-80-7395-233-4.

KOVÁČ, I. - ŽARNOVSKÝ, J. - ŽITŇANSKÝ, J. 2005 Vrstvy odolné proti opotrebeniu. In New Trends in Technology System Operation : Proceedings of the Seventh Conference with International Participation. Košice : Technical University, 2005. pp. 160-161. ISBN 80-8073-382-1.

KRCHNÁK, P. - BERNÁT, R. - BENEŠ, L. - HRUBEC, J. 2011. Hodnotenie kvality zvarov vysoko uhlíkatých ocelí. In TechMat 2011 - Perspektivní technologie a materiály pro technické aplikace. Pardubice : Univerzita Pardubice, 2011. s. 36. ISBN 978-80-7395-431-4.

MATERIAL HS 20, CORUS ENGINEERING STEEL. 2008. Certificate No. C000034134, Rotherham, United Kingdom.

STN EN 12517-1:2006-10. Non-destructive examination of welds. Radiographic examination of welded joints. Acceptance levels.

STN EN ISO 4136:2011-09. Destructive tests on welds in metallic materials. Transverse tensile test.

STN EN ISO 5173:2010-10. Destructive tests on welds in metallic materials. Bend tests.

STN EN ISO 5817:2008-03. Welding. Fusion-welded joints in steel, nickel, titanium and their alloys (beam welding excluded). Quality levels for imperfections (ISO 5817:2003, corrected version: 2005, including Technical Corrigendum 1:2006).

STN EN ISO 7438:2006-01. Metallic materials. Bend test.

TOLNAI, R. 2000. Strojárska technológia. Nitra : SPU. 2000. ISBN 80-7137-669-8.

TURŇA, M. 1989. Špeciálne metódy zvárania. Bratislava : ALFA. 1989. ISBN 80-05-00097-9.

ŽERNOVIČ, M. - MIKUŠ, R. - BERNÁT, R. 2006. Overenie technologického postupu pri naváraní práškových tvrdonávarov. In TechMat 06. Pardubice : Univerzita Pardubice, 2006. s. 111-114. ISBN 80-7194-902-7.

Contact address:

Ing. Rastislav Bernát, PhD., IWE; Slovak University of Agriculture in Nitra, Faculty of Engineering, Department of Quality and Engineering Technologies, Tr. A. Hlinku 2, 94976 Nitra, Slovak Republic, email: rastislav.bernat@uniag.sk 